\title{
Changes in the reduction state of ascorbate and glutathione, protein oxidation and hydrolysis leading to the development of dehydration intolerance in Triticum aestivum $\mathbf{L}$. seedlings
}

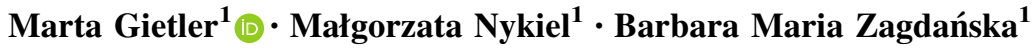

Received: 4 March 2015/Accepted: 26 October 2015/Published online: 28 October 2015

(C) The Author(s) 2015. This article is published with open access at Springerlink.com

\begin{abstract}
The present work demonstrates that the transition of wheat (Triticum aestivum L.) seedlings from dehydration tolerance to intolerance on the fifth day following imbibition is associated with a disturbance in cellular redox homeostasis. During germination the ratio of reduced (AsA) to oxidized ascorbate (DHA) was lower in the tolerant 4-day-old seedlings compared to the sensitive 6-day-old seedlings because of the lower ascorbate content in the former. The reduced glutathione (GSH) and total glutathione (GSH + GSSG) pools were higher in tolerant seedlings and remained higher upon dehydration. The development of dehydration intolerance with a seedling age coincided with a $50 \%$ loss of the total glutathione pool and a shift of GSH/GSSG to a more oxidized state. Activities of ascorbate peroxidase and glutathione reductase increased with water deficiency in both tolerant and sensitive seedlings but the three new activity bands appeared only in sensitive seedlings. The stable ratio of GSH/GSSG and a higher AsA/DHA ratio in sensitive seedlings did not prevent the enhanced production of $\mathrm{H} 2 \mathrm{O} 2$ and the peroxidation of lipids with dehydration. As a result, an increase in the protein carbonyl group and a significant decrease in the thiol groups were observed in dehydrated sensitive seedlings. Water deficiency enhanced the total
\end{abstract}

Electronic supplementary material The online version of this article (doi:10.1007/s10725-015-0133-z) contains supplementary material, which is available to authorized users.

Marta Gietler

marta_gietler@sggw.pl

1 Department of Biochemistry, Warsaw University of Life Sciences, Nowoursynowska 159, 02-776 Warsaw, Poland azocaseinolytic activity, mainly in sensitive seedlings. The highest increase in protein carbonylation and lowest azocaseinolytic activity was observed at the beginning of seedling dehydration (15-25\% WSD) being in a sensitive phase of growth. The presented results indicate that the development of dehydration intolerance during the transition of wheat seedlings from heterotrophic to autotrophic growth is associated with an alterations in protein oxidation.

Keywords Dehydration tolerance - Glutathione · Proteolysis - Redox potential $\cdot$ Wheat

\section{Introduction}

In their natural environment, plants may encounter a variety of unfavourable conditions such as drought, extreme temperatures, salinity and others that lead to plant dehydration. The limited availability of water results in a shift in the balance between the production and the elimination of reactive oxygen species (ROS). This changes alters the cellular redox state (Noctor et al. 2014). Plant survival depends on their ability to maintain redox homeostasis during unfavourable conditions. Homeostasis is maintained by the cellular redox buffers ascorbate (AsA) and reduced glutathione (GSH) as well as tocopherols, flavonoids and carotenoids and enzymatic scavengers such as superoxide dismutase, catalase, peroxidases, mono- and dehydroascorbate reductases and glutathione reductase. Both ascorbate (AsA) and glutathione (GSH) can scavenge ROS directly or indirectly as electron donors, e.g. ascorbate peroxidase (APX; EC 1.11.1.11). APX, in combination with the ascorbate-glutathione cycle, oxidizes AsA to dehydroascorbate (DHA). DHA is reduced by GSH- 
dependent dehydroascorbate reductase (DHAR). The resulting glutathione disulfide (GSSG) is reduced by NADPH-dependent glutathione reductase (EC 1.6.4.2). The ascorbate-glutathione cycle is not restricted to chloroplasts. It is also present in the cytoplasm, mitochondria and peroxisomes (Noctor and Foyer 1998). Changes in the glutathione redox state, defined by the reducing capacity of GSH (GSH concentration) and the half-cell reduction potential of the GSH/GSSG couple $\left(\mathrm{E}_{\mathrm{GSSG} / 2 \mathrm{GSH}}\right)$ has been proposed as a marker of the cellular redox state (Kranner et al. 2006).

ROS oxidize all types of cellular components (lipids, proteins, and DNA). Proteins are the major targets for ROS, representing approximately $70 \%$ of the oxidized molecules in the cell (Rinalducci et al. 2008). To avoid the toxic effects of the accumulation of oxidized proteins, they are selectively recognized and degraded (Lounifi et al. 2013). Plants developed several distinct proteolytic pathways in different cell compartments, but which proteases are involved in the removal of oxidized proteins is not well understood. Experimental evidence suggests that oxidatively damaged proteins may be removed by mitochondrial ATP-dependent proteases (Voos 2013) and by autophagic processes (Xiong et al. 2007).

A plant's ability to withstand severe dehydration is limited to mature seeds and pollen of higher plants and to groups of vascular angiosperm plants (Colville and Kranner 2010). Wheat (Triticum aestivum L.) seedlings tolerate a high water deficit up to the 5th day of germination, but the appearance of the first leaf from the coleoptile coincided with a susceptibility to dehydration (Miazek et al. 2001). One of the main reason of seedlings transition from tolerance to dehydration to sensitivity is supposed to be change of the hexose/sucrose ratio i.e. "cellular energy state" in the developing seedlings of monocots and legumes (Koch 2004; Bogdan and Zagdańska 2009). Thus, questions have been raised whether the switch from dehydration tolerance to intolerance during the early growth of wheat seedlings may be linked to changes in the cellular redox state or to the more specific metabolic processes. To address these questions, the redox state of seedlings has been evaluated on the basis of the ratio of reduced to oxidized ascorbate, reduced to oxidized glutathione and the activities of glutathione reductase and ascorbate peroxidase. The balance between ROS production and scavenging was assessed with respect to $\mathrm{H}_{2} \mathrm{O}_{2}$ content and lipid peroxidation level. Their effect on the regulation of protein oxidation was determined by analysing the concentration of carbonyl and thiol groups in the proteins. The removal of abnormal, mistranslated, damaged and/or unnecessary proteins under water deficiency was investigated for both dehydration tolerant and sensitive wheat seedlings.

\section{Materials and methods}

\section{Plant material}

All experiments were carried out on spring wheat (Triticum aestivum L.) cultivar Zadra obtained from the Strzelce Experimental Station of Plant Breeding and Acclimatization Institute-NRI group. Seeds were surface sterilized with $1 \%$ sodium hypochlorite $(\mathrm{NaOCl})$ for $20 \mathrm{~min}$ and then rinsed several times with distilled water. After soaking in water overnight at $4{ }^{\circ} \mathrm{C}$ in the dark, twenty-five seeds were placed side by side (embryos downwards) on a wet filter paper strip $(25 \mathrm{~cm} \times 5 \mathrm{~cm})$ and covered with the identical strip. The strips were rolled and placed vertically into plastic boxes containing Knop's solution supplemented with Hoagland's micronutrients. The seedlings were grown in a growth chamber at $23{ }^{\circ} \mathrm{C}$ (daytime) and $16^{\circ} \mathrm{C}$ (night) with a photosynthetic photon flux density (PPFD) of $260 \mu \mathrm{mol} \mathrm{m} \mathrm{m}^{-2} \mathrm{~s}^{-1}$ for $8 \mathrm{~h}$ and $70-80 \%$ humidity. The nutrient solution was drained and the seedlings were allowed to dehydrate for 4 days in a growth chamber (under the identical conditions) to initiate a water deficit in the 4- and 6-day-old seedlings. The rate of seedling dehydration was determined as percentage of water saturation deficit (WSD) after a dehydration period calculated according to Turner (1981) as follows:

$$
\begin{aligned}
W S D= & \frac{\text { Water saturated mass }- \text { actual fresh mass }}{\text { Water saturated mass }- \text { dry mass }} \\
& \times 100 \%
\end{aligned}
$$

in which the water saturated mass of the sample represents the mass of the sample after submersion in water overnight (in the dark). The dry mass was determined after drying at $70{ }^{\circ} \mathrm{C}$ overnight. The seedlings were rehydrated for $24 \mathrm{~h}$. The percent of survived seedlings was calculated as the number of seedlings resuming elongative growth. Dehydration tolerance of 4- or 6-day-old seedlings was expressed as the percentage of seedling survival following 4 days of severe dehydration.

\section{Ascorbate content and ascorbate peroxidase activity}

The ascorbate content was assayed using the method described by Omaye et al. (1979). Seedling shoots (1 g) were homogenized in $0.1 \mathrm{M} \mathrm{HCl}$. After filtration, the homogenate was centrifuged at $16,000 \times g$ for $15 \mathrm{~min}$ at $4{ }^{\circ} \mathrm{C}$. The supernatant was neutralized with $\mathrm{NaOH}$ and phosphate buffer (150 mM, pH 7.4) was added. To determine total ascorbate content, half of the separated extract was incubated for $15 \mathrm{~min}$ at room temperature with $10 \mathrm{mM}$ of DTT and $0.5 \%$ (w/v) N-ethylmaleimide (NEM). Both solutions were treated with $10 \%(\mathrm{w} / \mathrm{v}) \mathrm{TCA}$ (trichloroacetic acid). Solutions were centrifuged at $16,000 \times g$ for $3 \mathrm{~min}$. 
Supernatants were mixed with $4 \%$ (w/v) 2,2'-bipyridine, $42.5 \%(\mathrm{v} / \mathrm{v})$ phosphoric acid and $3 \%(\mathrm{w} / \mathrm{v})$ ferric chloride and incubated for $45 \mathrm{~min}$ at $37{ }^{\circ} \mathrm{C}$. The absorbance was then measured at $525 \mathrm{~nm}$ and compared to a standard curve.

The ascorbate peroxidase activity (APX, EC 1.11.1.11) was determined according to the method described by Nakano and Asada (1981). Samples (1 g) of fresh shoots were ground to a powder in liquid nitrogen. A $5 \mathrm{ml}$ aliquot of cold potassium phosphate buffer $(50 \mathrm{mM}, \mathrm{pH} 7.0)$ containing $5 \mathrm{mM}$ EDTA, $2 \mathrm{mM}$ ascorbate and $0.5 \%(\mathrm{w} / \mathrm{v})$ PVP was added. The homogenate was centrifuged at $16,000 \times g$ for $20 \mathrm{~min}$ at $4{ }^{\circ} \mathrm{C}$. Enzyme activity was analysed in the reaction mixture containing $0.1 \mathrm{mM} \mathrm{H}_{2} \mathrm{O}_{2}$ and $30 \mu \mathrm{l}$ enzyme extract at a total volume of $1 \mathrm{ml}$. The change in absorbance at $290 \mathrm{~nm}$ was recorded every $10 \mathrm{~s}$ for 3 min. The APX activity was calculated using an extinction coefficient for ascorbate of $2.8 \mathrm{mM}^{-1} \mathrm{~cm}^{-1}$ and expressed as $\mu \mathrm{mol}$ of oxidized ascorbate per minute per mg protein.

Samples were subjected to discontinuous PAGE without denaturing as described by Laemmli (1970). The carrier buffer contained $2 \mathrm{mM}$ ascorbate. Gels were pre-run for $30 \mathrm{~min}$ to allow the ascorbate, present in the carrier buffer, to enter the gel prior to the application of the samples (Mittler and Zilinskas 1993). Gels were incubated in sodium phosphate buffer $(50 \mathrm{mM}, \mathrm{pH} 7.0)$ containing $2 \mathrm{mM}$ ascorbate and $2 \mathrm{mM} \mathrm{H}_{2} \mathrm{O}_{2}$ for 20 min following electrophoretic separation. The gels were washed with buffer for $1 \mathrm{~min}$, and submerged in potassium phosphate buffer $(50 \mathrm{mM}, \mathrm{pH} 7.8)$ containing $28 \mathrm{mM}$ tetramethyl ethylene diamine and $2.45 \mathrm{mM}$ nitroblue tetrazolium with gentle agitation. The reaction was continued for 10-15 min and stopped by a brief wash in water. Protein content in the supernatant was determined according to the method of Bradford (1976). BSA was the standard.

\section{Glutathione content and glutathione reductase activity}

Reduced glutathione was assayed following the method described by Gronwald et al. (1987). Seedling shoots were ground to a powder in liquid nitrogen using a chilled mortar and pestle. The powder $(200 \mathrm{mg})$ was homogenized in $7.57 \mathrm{mM}$ sodium ascorbate and incubated for $30 \mathrm{~min}$ at $0{ }^{\circ} \mathrm{C}$. After filtration the homogenate was centrifuged at $16,000 \times g$ for $15 \mathrm{~min}$ at $4{ }^{\circ} \mathrm{C}$. The supernatant was divided into two portions: one for the total glutathione (GSH + GSSG) assay and a second for the oxidized glutathione (GSSG) assay. For the GSSG assay, $10 \mathrm{mM}$ NEM was dissolved in sodium-phosphate buffer $(125 \mathrm{mM}, \mathrm{pH}$ 7.5) containing $5 \mathrm{mM}$ EDTA, and then added to $0.4 \mathrm{ml}$ of supernatant to mask the thiol group of GSH by NEM. After mixing and incubating for $70 \mathrm{~min}$, the NEM was removed by five ether extractions. Glutathione was determined by the DTNB [5,5'-dithiobis(2-nitrobenzoic acid)]-recycling method described by Ellman (1959). The reaction mixture $(\mathrm{pH}$ 7.0) for the assay of GSSG or (GSH + GSSG) consisted of $10 \mathrm{mM}$ phosphate, $0.5 \mathrm{mM}$ NADPH, 0.12 units glutathione reductase and supernatant. An increase in the absorbance at $412 \mathrm{~nm}$ was measured after the addition of DTNB. The total glutathione (GSH + GSSG) and GSSG contents were calculated using a standard curve. For the glutathione reductase (GR, EC 1.6.4.2) activity assay, $0.1 \mathrm{~g}$ of seedling shoots were homogenized with potassium phosphate $(50 \mathrm{mM}, \mathrm{pH} 7.5)$ containing $2 \mathrm{mM}$ EDTA and $1 \%$ PVP (w/v) at $4{ }^{\circ} \mathrm{C}$. The homogenate was filtered through four layers of cheesecloth and centrifuged at $16,000 \times g$ for $20 \mathrm{~min}$. Glutathione reductase in crude extract was assayed by the oxidation of NADPH at $340 \mathrm{~nm}$ (extinction coefficient $6.2 \mathrm{mM}^{-1} \mathrm{~cm}^{-1}$ ) as described by Rao et al. (1996). The $1 \mathrm{ml}$ assay mixture contained potassium phosphate buffer (50 mM, pH 7.0), $2 \mathrm{mM}$ EDTA, $0.2 \mathrm{mM}$ NADPH, $0.5 \mathrm{mM}$ GSSG, and leaf extract. The assays were initiated by the addition of NADPH at $25{ }^{\circ} \mathrm{C}$. GR activity, expressed as NADPH oxidation per minute per $\mathrm{mg}$ of protein, was measured by the absorbance decrease per minute ( $5 \mathrm{~min}$ period).

\section{Lipid peroxidation}

Lipid peroxidation was measured according to the method of Heath and Packer (1968), and expressed as thiobarbituric acid reactive substances (TBARS). A $200 \mathrm{mg}$ shoot was homogenized in $10 \%$ TCA (w/v) containing $0.25 \%$ $(w / v)$ thiobarbituric acid and centrifuged at $10,000 \times g$ for $20 \mathrm{~min}$. The supernatant was collected and heated for $25 \mathrm{~min}$ at $95{ }^{\circ} \mathrm{C}$. It was cooled in an ice bath and centrifuged at $3000 \times g$ for $15 \mathrm{~min}$. The absorbance of the supernatant was measured at $532 \mathrm{~nm}$, with a reading at $600 \mathrm{~nm}$ subtracted (nonspecific turbidity). The TBARS content was determined using an extinction coefficient of $155 \mathrm{mM}^{-1} \mathrm{~cm}^{-1}$ (to quantify lipid peroxides). It was expressed as nmol TBARS $\mathrm{g}^{-1}$ fresh weight.

\section{Hydrogen peroxide determination}

The hydrogen peroxide $\left(\mathrm{H}_{2} \mathrm{O}_{2}\right)$ content in the shoots was determined according to the method described by Jana and Choudhuri (1981). The $\mathrm{H}_{2} \mathrm{O}_{2}$ level was measured using titanium chloride. Shoots $(100 \mathrm{mg})$ were homogenized in phosphate buffer $(50 \mathrm{mM}, \mathrm{pH} 6.5)$ and centrifuged at $6000 \times g$ for $25 \mathrm{~min}$. The supernatant was mixed with $0.1 \%(\mathrm{w} / \mathrm{v})$ titanium chloride in $20 \%(\mathrm{v} / \mathrm{v})$ $\mathrm{H}_{2} \mathrm{SO}_{4}$ and centrifuged at $6000 \times g$ for $15 \mathrm{~min}$. The absorbance of the titanium peroxide complex was 
measured at $410 \mathrm{~nm}$ and calculated using an extinction coefficient of $0.28 \mu \mathrm{M}^{-1} \mathrm{~cm}^{-1}$.

\section{Estimation of protein thiols}

The protein thiol content was determined according to de Kok and Kuiper (1986). Shoots (150 mg) were homogenized in $5 \mathrm{ml}$ of $0.15 \%(\mathrm{w} / \mathrm{v})$ sodium ascorbate, and the homogenate was centrifuged at $22,000 \times g$ for $10 \mathrm{~min}$ at $4{ }^{\circ} \mathrm{C}$. To measure the total thiol $(-\mathrm{SH})$ content, $0.5 \mathrm{ml}$ of supernatant was mixed with $1 \mathrm{ml}$ Tris- $\mathrm{HCl}(0.2 \mathrm{M}, \mathrm{pH}$ 8.0), $0.5 \mathrm{ml} 8 \%$ (w/v) SDS and $0.1 \mathrm{ml} 10 \mathrm{mM}$ DTNB. DTNB was freshly prepared in potassium phosphate buffer (0.02 M, pH 7.0). After $15 \mathrm{~min}$ of incubation at $30^{\circ} \mathrm{C}$, a yellow colour developed that was measured at $415 \mathrm{~nm}$. A correction was performed for the absorbance of the incubation mixture in the absence of DTNB (replaced with distilled water) and in the absence of supernatant (replaced with $0.15 \%$ sodium ascorbate). The homogenate was deproteinized by incubating it in a water bath at $100{ }^{\circ} \mathrm{C}$ for $4 \mathrm{~min}$, followed by centrifugation at $22,000 \times g$ for $10 \mathrm{~min}$ to measure the non-protein thiols. A $0.5 \mathrm{ml}$ aliquot of deproteinized extract $-\mathrm{SH}$ content was determined. The content of protein thiols was calculated by subtracting the content of non-protein thiols from the total thiols, and

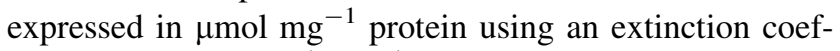
ficient of $13,600 \mathrm{M}^{-1} \mathrm{~cm}^{-1}$.

\section{Protein-bound carbonyl content}

The content of protein bound carbonyls was determined as described by Levine et al. (1994). Shoot samples (200 mg fresh weight) were homogenized at $4{ }^{\circ} \mathrm{C}$ in a $3.0 \mathrm{ml}$ sodium phosphate buffer (50 mM, pH 7.4) containing 1 mM EDTA. The homogenate was centrifuged at $6000 \times g$ for $10 \mathrm{~min}$ at $4{ }^{\circ} \mathrm{C}$. An $800 \mu \mathrm{l}$ aliquot of $10 \mathrm{mM}$ DNPH (2,4-dinitrophenyl hydrazine) in $2.5 \mathrm{M} \mathrm{HCl}$ was added to $200 \mu \mathrm{l}$ of sample. Individual blank samples were incubated in $2.5 \mathrm{M}$ $\mathrm{HCl}$. Samples were incubated (in the dark) for $1 \mathrm{~h}$ at room temperature and were vortexed every $15 \mathrm{~min}$. After adding of $1 \mathrm{ml}$ of $20 \%$ (w/v) TCA, samples were incubated on ice for $5 \mathrm{~min}$ and centrifuged at $10,000 \times g$ for $10 \mathrm{~min}$ at $4{ }^{\circ} \mathrm{C}$. The pellet was resuspended in $1 \mathrm{ml}$ of an ethanol/ethyl acetate mixture (1:1), vortexed and centrifuged at $10,000 \times g$ for $10 \mathrm{~min}$ at $4{ }^{\circ} \mathrm{C}$. An ethanol/ethyl acetate wash was repeated three times. The cleaned pellet was resuspended in $1 \mathrm{ml}$ of $6 \mathrm{M}$ guanidine hydrochloride in potassium phosphate buffer $(20 \mathrm{mM}, \mathrm{pH} 2.3)$. Samples were centrifuged at $10,000 \times g$ for $10 \mathrm{~min}$ at $4{ }^{\circ} \mathrm{C}$ to remove any debris. The absorbance was measured at $375 \mathrm{~nm}$. The carbonyl content was calculated using a molar absorption coefficient for aliphatic hydrazones of $22,000 \mathrm{M}^{-1} \mathrm{~cm}^{-1}$ and expressed in $\mu \mathrm{mol}$ carbonyl $\mathrm{mg}^{-1}$ protein.

\section{Measurement of azocaseinolytic activity}

Shoot tissue ( $1 \mathrm{~g}$ ) was ground to a powder in liquid nitrogen and extracted with $5 \mathrm{ml}$ of the pre-cooled extraction buffer Tris- $\mathrm{HCl}$ (50 mM, pH 7.2) with $5 \mathrm{mM} \beta$ mercaptoethanol and $0.2 \mathrm{~g}$ of insoluble PVP. The homogenate was filtered and centrifuged at $15,000 \times g$ for $10 \mathrm{~min}$ at $4{ }^{\circ} \mathrm{C}$. The supernatant was used for the enzyme assay. The reaction mixture contained $50 \mu$ l of the enzyme extract, $0.15 \mathrm{ml}$ of $0.5 \%(\mathrm{w} / \mathrm{v})$ azocasein and $0.3 \mathrm{ml}$ citrate buffer $(0.25 \mathrm{M}, \mathrm{pH} 5.0)$. After $2 \mathrm{~h}$ at $37{ }^{\circ} \mathrm{C}$, the reaction was stopped by adding $1 \mathrm{ml}$ of $12 \%$ (w/v) TCA. The acid-soluble products were determined spectrophotometrically at $340 \mathrm{~nm}$. One unit of azocaseinolytic activity was defined as the amount of the enzyme that resulted in a 0.01 increase in $\mathrm{A}_{340}$. To determine the activity of the specific proteinases, the following inhibitors were added: $1.0 \mathrm{mM}$ iodoacetate (cysteine proteinases activity), $5 \mathrm{mM}$ of PMSF dissolved in methanol (serine proteinases activity), $10 \mathrm{mM}$ EDTA (metalloproteinases activity) and $1 \mu \mathrm{g}$ of pepstatine A dissolved in DMSO (aspartate proteinases activity). Samples were preincubated with inhibitor for $1 \mathrm{~h}$ prior to the addition of azocasein.

\section{Statistical analysis}

For the experiment (three independent experiments in three replicates, $\mathrm{n}=9$ ), statistical analysis using a two-way analysis of the variance (ANOVA; $P<0.05$ ) was performed using Free Statistics Software, Office for Research Development and Education; Wessa, 2014. A Tukey's HSD (honestly significant difference) post hoc test was used to evaluate differences among the means $(P<0.05)$.

\section{Results}

\section{The effect of wheat seedling age on survival following severe dehydration}

The rate of dehydration of the wheat seedlings, determined as a percentage of the water saturation deficit (WSD), increased gradually up to $96 \mathrm{~h}$ of dry treatment. It achieved the similar final value in four- $(62.7 \pm 2.3 \%$ WSD $)$ and 6-day-old (66.5 $\pm 2.5 \%$ WSD) seedlings. After a $24 \mathrm{~h}$ rehydration period seedlings recovered to the identical water deficit noted in both types of seedlings before dehydration. The WSD of the hydrated, dehydrated and rehydrated seedlings did not depend on seedling age. Irrespective of the attained identical water deficit after dehydration and rehydration periods, the percentage of survived seedlings varied (based on their ability to resume elongative growth after rehydration). Four-day-old wheat 
seedlings almost completely $(87 \%)$ survived severe dehydration. Half $(52 \%)$ of the 6-day-old seedlings survived. There is no direct relationship between water deficit and survival of wheat seedlings during post-germination growth (Miazek et al. 2001). The 4-day-old seedlings were dehydration tolerant, but 6-day-old seedlings were dehydration sensitive (severe dehydration was a criterion for dehydration tolerance). The observed development of dehydration intolerance was associated with the stage of seedling growth, as previously suggested (Sperdouli and Moustakas 2014).

\section{Changes in the ascorbate and glutathione pool}

The effect of dehydration on changes in the ascorbate and glutathione pools was investigated to determine the relationship between dehydration tolerance and the redox state of seedlings. The ratio of reduced (AsA) to oxidized ascorbate (DHA) was lower in the tolerant 4-day-old tolerant seedlings compared to the sensitive 6-day-old seedlings because of the lower ascorbate (AsA) content in the former (Fig. 1A). The high AsA/DHA ratio in sensitive seedlings was maintained up to $65 \%$ WSD. This ratio decreased slowly in tolerant seedlings to the level observed in fully turgid seedlings. The lower AsA/DHA ratio in the tolerant seedlings corresponded to a lower activity of ascorbate peroxidase (APX; Fig. 1C). The specific activity of APX was higher in the control, well watered 6-day-old seedlings and increased with water deficiency in both tolerant and sensitive plants. The higher activity of this enzyme (6-day-old seedlings compared to 4-day-old seedlings) may be explained by the higher activity of the electrophoretic bands revealed by native PAGE, with ascorbate as a substrate, and to the three new activity bands that appeared upon dehydration (see electronic supplementary material).

In sensitive wheat seedlings, the total pool of reduced (GSH) and oxidized (GSSG) glutathione (Fig. 1B) was approximately $50 \%$ lower compared to the tolerant seedlings. The difference in the total glutathione pool between 6- and 4-day-old seedlings explains the lower content of GSH (6-day-old seedlings compared to 4-day-old seedlings). The ratio of GSH to GSSG, in sensitive seedlings, was approximately half of that in tolerant seedlings. The total glutathione pool increased several times in response to dehydration, but the GSH/GSSG ratio did not change in comparison to the fully turgid seedlings. Glutathione reductase activity (Fig. 1D) was higher for fully turgid
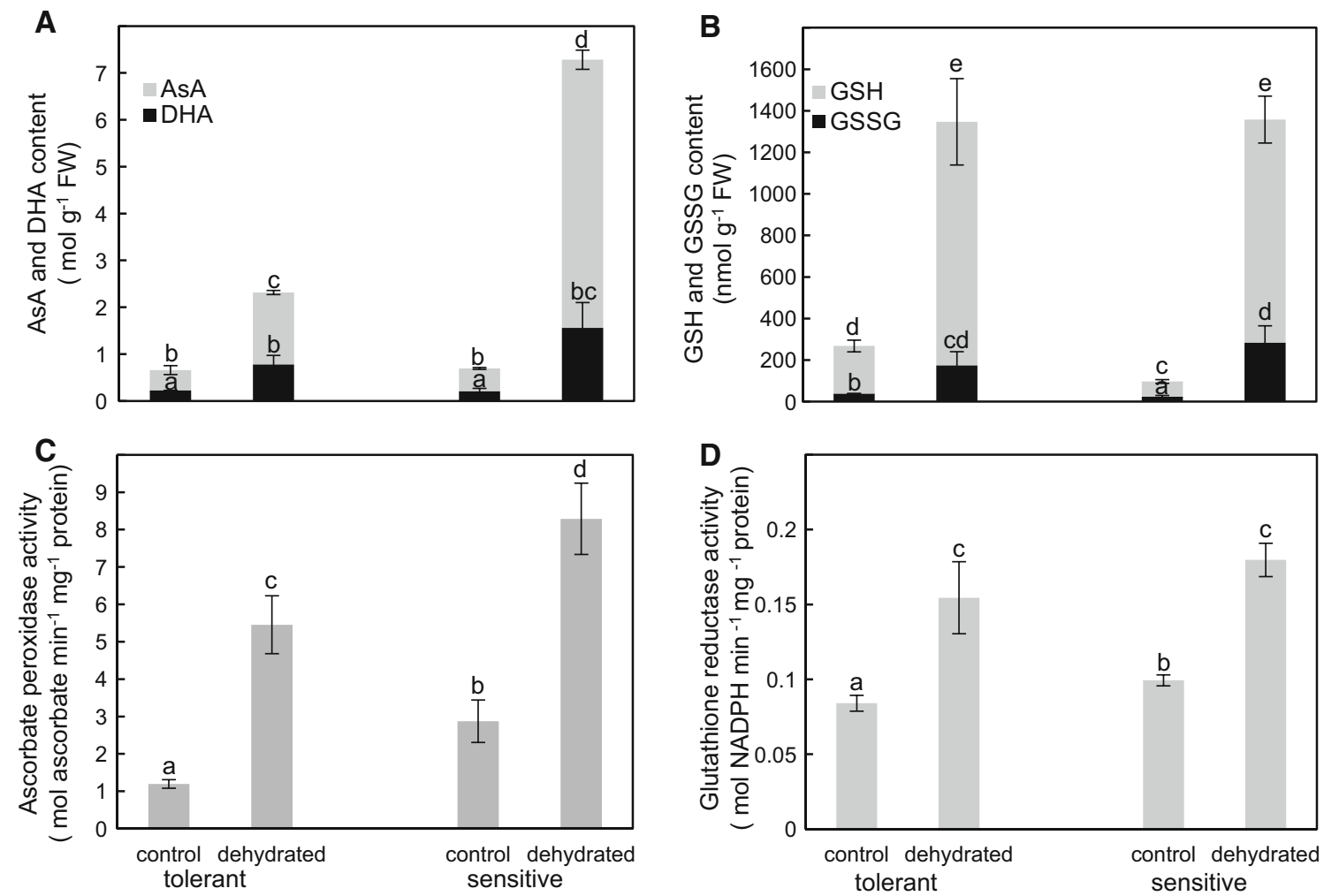

Fig. 1 Effect of dehydration on reduced and oxidized ascorbate (A), reduced and oxidized glutathione (B) contents, ascorbate peroxidase (C) and glutathione reductase (D) activities in fully turgid (control) and dehydrated wheat seedlings in tolerant (4 days old) and sensitive

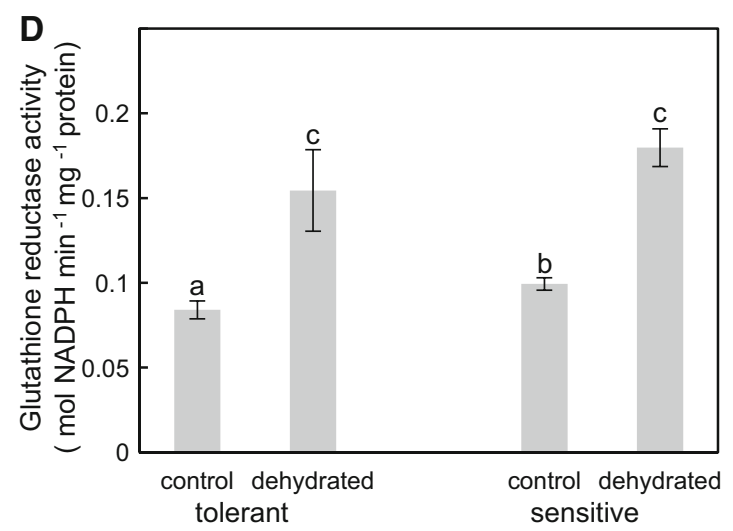

(6 days old) phases of growth. Vertical bars indicate $\pm \mathrm{SD}$ of the mean $(\mathrm{n}=9)$. Bars headed by different letters differ significantly $(P \leq 0.05)$ according to the Tukey's test 
sensitive seedlings, and increased significantly in response to dehydration. The activity of glutathione reductase did not differentiate dehydrated 4-day-old seedlings from the older seedlings. The observed differences, in total pools of ascorbate and glutathione, provide additional information. The higher GSH/AsA ratio, in both fully turgid and dehydrated seedlings in the tolerant phase of growth, implies that the glutathione reductase-based maintenance of the balance between the GSH and ascorbate pools maintains the cellular redox state.

\section{Effect of dehydration on lipid peroxidation, $\mathrm{H}_{2} \mathrm{O}_{2}$ content and protein oxidation}

Lipid peroxidation during a water deficit was assessed using TBARS content in the well- watered control and dehydrated seedlings (Fig. 2A). The concentration of TBARS did not differ for the fully turgid control seedlings. The TBARS content increased at the highest water deficit and was higher in the sensitive seedlings compared to the tolerant seedlings. Similarly, the concentration of $\mathrm{H}_{2} \mathrm{O}_{2}$ in the control seedlings was identical and independent of their tolerance (Fig. 2B). At $65 \%$ WSD, the concentration of
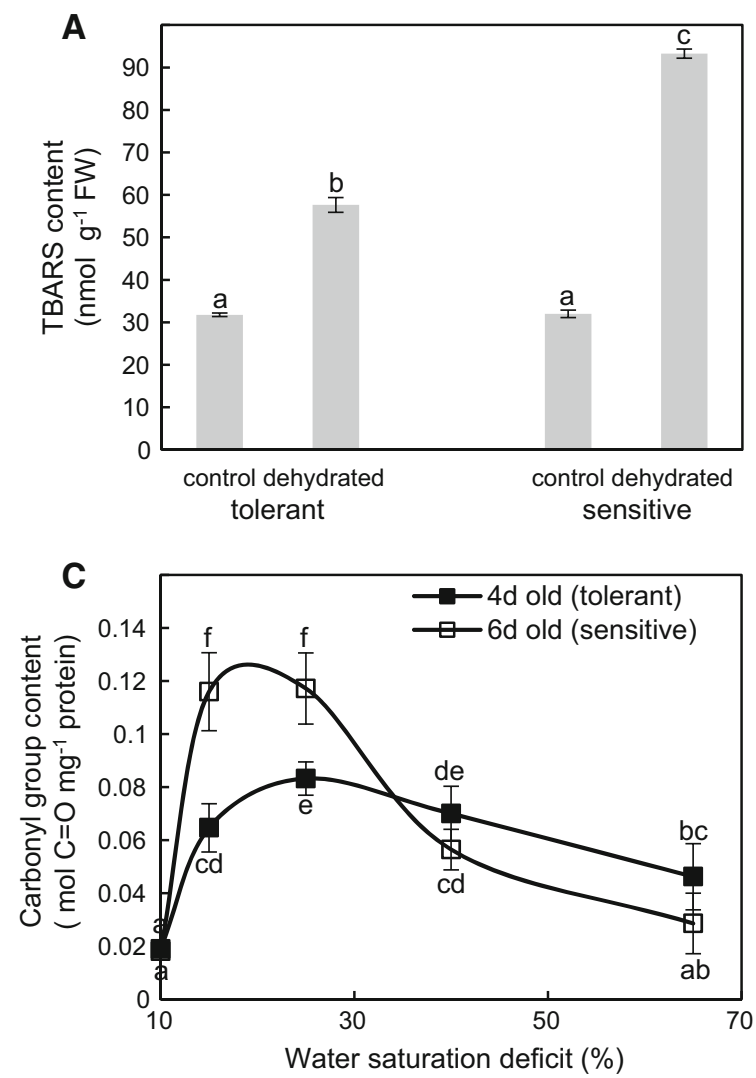

Fig. 2 Changes in lipid peroxidation as TBARS (A) and the hydrogen peroxide $\left(\mathrm{H}_{2} \mathrm{O}_{2}\right)$ content $(\mathbf{B})$, oxidative damage to the proteins as carbonylation $(\mathbf{C})$ and the protein thiol content (D) of fully turgid (control) and dehydrated wheat seedlings in tolerant (4 days
$\mathrm{H}_{2} \mathrm{O}_{2}$ was approximately threefold higher in the sensitive seedlings compared to the tolerant seedlings. The concentration of $\mathrm{H}_{2} \mathrm{O}_{2}$ increased two- and six-fold for the tolerant and sensitive seedlings, respectively (compared to the hydrated seedlings).

The concentration of carbonyl and thiol groups in proteins was determined to examine the effect of increased $\mathrm{H}_{2} \mathrm{O}_{2}$ concentration on protein oxidation in dehydrated wheat seedlings. The carbonyl group content $(0.02 \mu \mathrm{mol}$ $\mathrm{C}=\mathrm{O} \mathrm{mg}{ }^{-1}$ protein) was identical for the control, hydrated sensitive and tolerant seedlings (Fig. 2C). The carbonyl group content increased upon dehydration. The highest increase in protein carbonylation was observed at the beginning of seedling dehydration (15-25\% WSD). Carbonyl group content was higher in sensitive 6-day-old seedlings $\left(0.12 \mu \mathrm{mol} \mathrm{C}=\mathrm{O} \mathrm{mg}^{-1}\right.$ protein $)$ compared to tolerant 4-day-old seedlings $\left(0.08 \mu \mathrm{mol} \mathrm{C}=\mathrm{O} \mathrm{mg}^{-1}\right.$ protein). The content of protein carbonyl groups decreased in both types of seedlings but remained higher in comparison to the control seedlings.

The content of the SH-groups in soluble proteins increased with seedling age and was approximately $60 \%$ higher in 6-day-old seedlings compared to 4-day-old
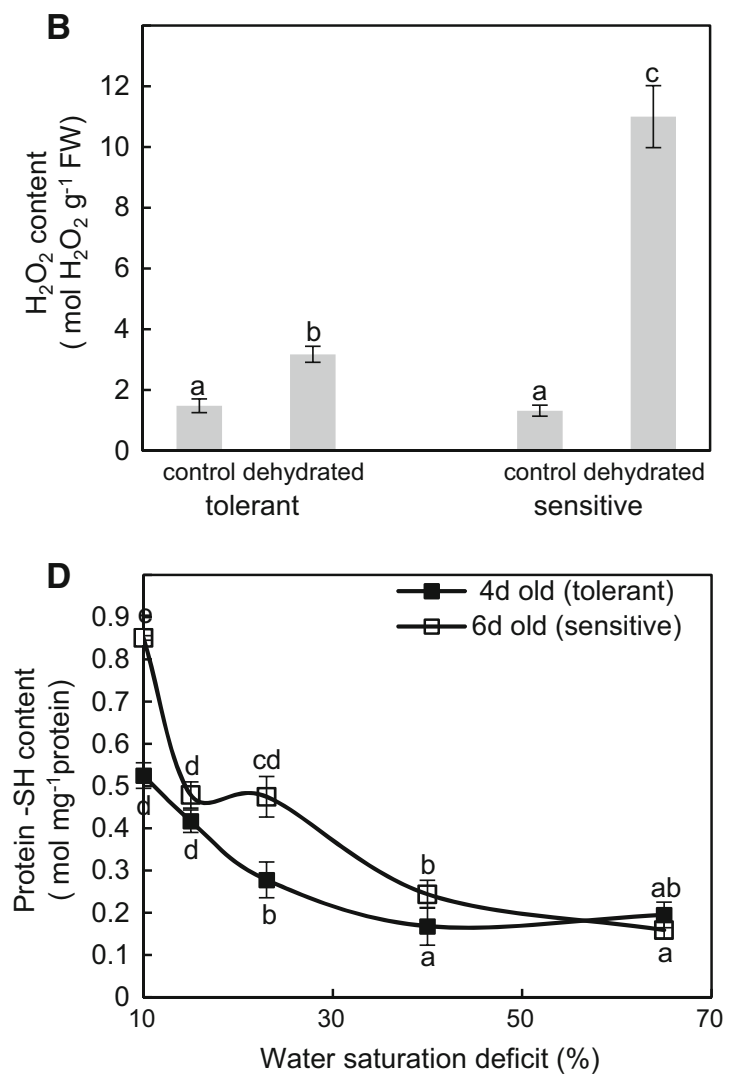

old) and sensitive (6 days old) phases of growth. Vertical bars indicate $\pm \mathrm{SD}$ of the mean $(\mathrm{n}=9)$. Bars headed by different letters differ significantly $(P \leq 0.05)$ according to the Tukey's test 
seedlings (Fig. 2D). Dehydration resulted in a significant decrease in the content of SH-proteins (independent of seedling age). The protein SH content was reduced to $19 \%$ of the control sensitive seedlings and to $37 \%$ of the control tolerant seedlings.

\section{Response of proteolysis to dehydration}

The content of soluble protein (per gram of dry weight) was approximately $20 \%$ higher in 6-day-old seedlings compared to 4-day-old seedlings (Fig. 3A). The dehydration of seedlings to approximately $25 \% \mathrm{WSD}$ reduced the protein content by approximately $70 \%$ in the sensitive
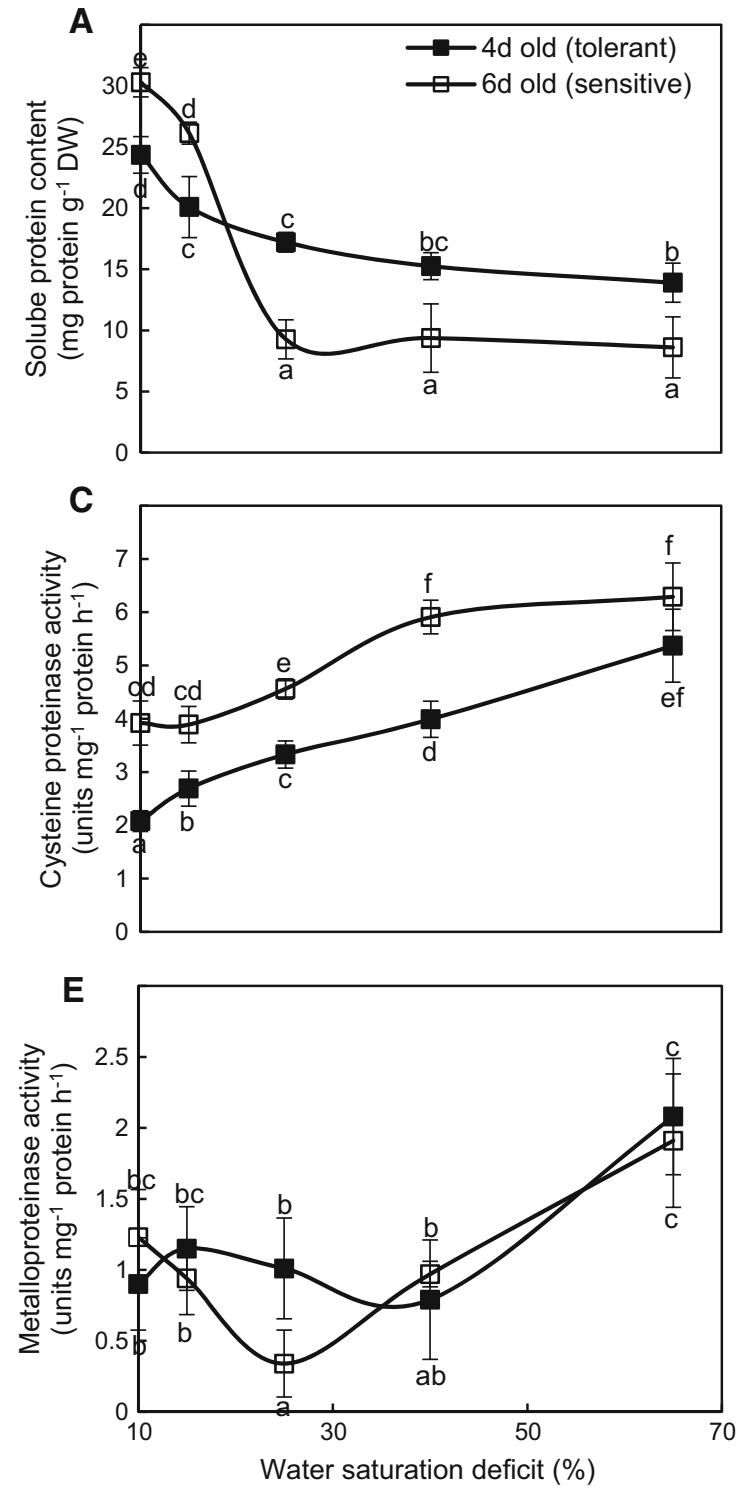

Fig. 3 Changes in the soluble protein content (A), azocaseinolytic activity (B) and cysteine (C), serine (D) metallo- $(\mathbf{E})$ and aspartate (F) proteinase activities in 4 days old (closed symbols) and 6 days old seedlings and approximately $30 \%$ in the tolerant seedlings. The final water deficit (65\% WSD) lowered the content of soluble proteins in the tolerant seedlings to approximately $57 \%$ of control, hydrated seedlings. The identical water deficit lowered the soluble protein content in the sensitive seedlings to $28 \%$ of the control, hydrated seedlings.

To evaluate the effect of dehydration on protein degradation, azocaseinolytic activity in crude extracts from wheat seedlings was evaluated (Fig. 3B). In a sensitive phase of seedling growth (6 days old) the total azocaseinolytic activity of the control hydrated wheat seedlings was higher (12.57 units $\mathrm{mg}^{-1}$ protein $\mathrm{h}^{-1}$ ) than seedlings in a tolerant phase of seedling growth $\left(7.24\right.$ units $\mathrm{mg}^{-1}$ protein $\left.\mathrm{h}^{-1}\right)$. A
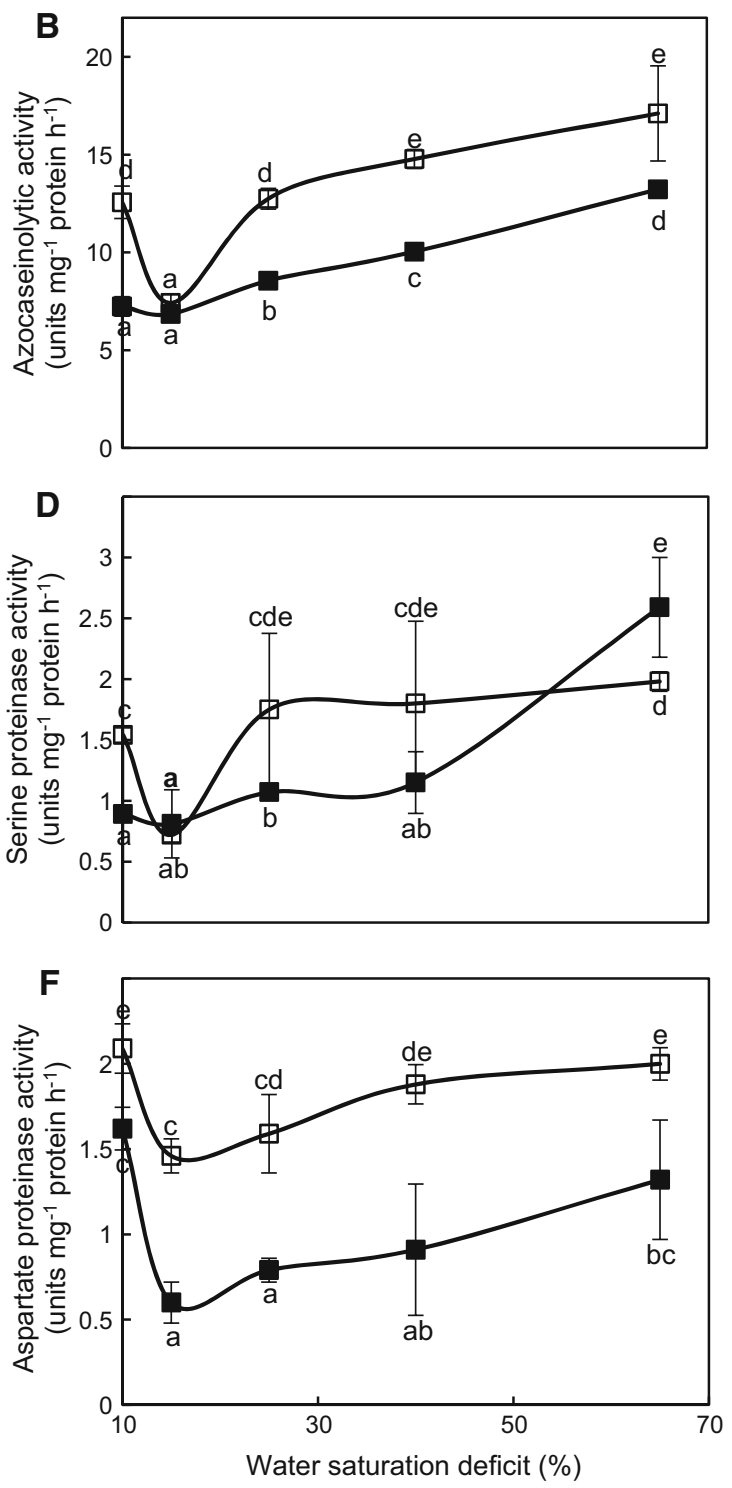

(open symbols) wheat seedlings upon dehydration. Vertical bars indicate $\pm \mathrm{SD}$ of the mean $(\mathrm{n}=9)$. Bars headed by different letters differ significantly $(P \leq 0.05)$ according to the Tukey's test 
more detailed analysis of azocaseinolytic activity, assayed with the use of specific inhibitors, revealed significant inhibition (approximately $30 \%$ ) of cysteine proteinases in both types of seedlings (Fig. 3C). Serine (Fig. 3D) and metalloproteinases (Fig. 3E), as identified by their respective inhibitors (PMSF and EDTA), represented approximately $12 \%$ of the total proteolytic activity irrespective of seedling age. Pepstatin A, an inhibitor of aspartic proteinases (Fig. 3F), modified the proteolytic activity to a similar extent (22 and $17 \%$ for 4- and 6-day-old seedlings, respectively).

Proteolysis was initially reduced in sensitive seedlings in response to water deficiency. Azocaseinolytic activity remained at the level noted for fully turgid tolerant 4-dayold seedlings (Fig. 3B). At higher water deficiency (30\% WSD), the intensity of azocasein hydrolysis increased in both types of seedlings. At the most severe water deficit, the intensities were approximately 80 and $36 \%$ higher in tolerant and sensitive seedlings, respectively, than in the control. These differences were associated with changes in the activities of particular proteinases (Fig. 3C-F). The cysteine proteinases were preferentially enhanced under a water deficiency (Fig. 3C). The activities of serine and metalloproteinases fluctuated during dehydration, with a tendency to decrease at $15 \%$ WSD. At higher water deficits, the activity of serine proteinases was higher in the tolerant seedlings than in the sensitive seedlings. The activity of aspartic proteinases remained stable, even at higher water deficits. Its participation in total azocaseinolytic activity decreased by half in the tolerant seedlings.

\section{Discussion}

We demonstrated that the observed inability of 6-day-old seedlings to tolerate the identical water deficit compared to 4-day-old seedlings is associated with a disturbance in cellular redox homeostasis and the reduced and oxidized ascorbate and glutathione pools. A loss of dehydration tolerance on the fifth day following imbibition is accompanied by a higher AsA content and AsA/DHA ratio in 6-day-old seedlings compared to 4-day-old seedlings. The higher AsA content may be because of the de novo biosynthesis of AsA required for both cell division and expansion (Considine and Foyer 2014) and a higher AsA recycling ability. In response to water deficiency, seedlings resistant to dehydration demonstrated a steady reduced status of ascorbate because of the paralleled increase in DHA and AsA. A significant increase in AsA content and a higher AsA/DHA ratio was been observed for seedlings sensitive to dehydration. This significant increase in AsA content may be triggered by accumulated $\mathrm{H}_{2} \mathrm{O}_{2}$ as was previously observed for Mediterranean shrub (Jubany-Mari et al. 2009). The accumulation of $\mathrm{H}_{2} \mathrm{O}_{2}$ in cells may be prevented by ascorbate peroxidase, the major $\mathrm{H}_{2} \mathrm{O}_{2}$ reducing peroxidase in plants, via the ascorbate-glutathione pathway (Noctor et al. 2014). In response to a water deficiency, ascorbate peroxidase activity increased in both types of seedlings. A greater increase was observed in tolerant seedlings. The higher activity of this enzyme is a common response of various plant species (maize, wheat, beans, rice and alfalfa) to drought (Gill and Tuteja 2010). The presence of three new activity bands of ascorbate peroxidase (6-day-old seedlings) confirms enhanced activity of this enzyme in wheat seedlings upon dehydration. Various abiotic stresses stimulated the activity of some APX isozymes from the ascorbate peroxidase isoenzymatic spectrum in spinach (Yoshimura et al. 2000). APX5 isoenzymatic bands were more intense in drought tolerant compared to drought sensitive genotypes of pearl millet (Kholová et al. 2011). Although the differential roles of various isoenzymes are well documented (Yoshimura et al. 2000; Chen et al. 2014), the importance of particular APX isoenzymes in plant acclimation to drought remains unclear.

The GSH pool and total glutathione (GSH + GSSG) content is higher in tolerant seedlings than sensitive seedlings. The lowered level of GSH with germination confirms the previous report for higher plants (Tommasi et al. 2001). The rise in activities of ascorbate peroxidase and glutathione reductase (GR) with seedling age suggest the increased utilization of AsA and GSH with the progression of germination. A drastically lowered GSH/AsA ratio and the higher activities of enzymes responsible for their reduced forms with the seedling age, indicate a their finetuned regulation with phases of plant development.

The importance of the GSH + GSSG pool and the GSH/ GSSG ratio in dehydration tolerance was confirmed by our experiments. The development of dehydration intolerance with seedling age, referred to as $50 \%$ seedling survival, coincided with a $50 \%$ loss of the total glutathione (GSH + GSSG) pool and a shift of GSH/GSSG to a more oxidized state (6.0-3.1). This finding is consistent with a decline in total GSH content and the lower ratio of GSH to GSSG reported for the germinating seeds and seedlings of many species (Tomassi et al. 2001; Pyngrope et al. 2013). The significant increase in GSSG levels during the early stages of development was also reported during the differentiation of tracheary elements in Zinnia sp. cells and Arabidopsis thaliana roots (Henmi et al. 2005) and seedlings (Frottin et al. 2009). The reduction potential is also dependent on the concentration of total glutathione $([\mathrm{GSH}]+2[\mathrm{GSSG}])$. The oxidation state of the glutathione pool should be considered (Meyer and Hell 2005). For wheat seedlings, the oxidation state of the glutathione 
pool, expressed as the degree of oxidation, increased from 22.9 to $39.3 \%$ with the seedling age (Fig. 1B). An observed shift of GSH/GSSG, to a more oxidized state with a seedling age, resulted in more positive values for half-cell reduction potential of the GSH/GSSG couple $\left(E_{\mathrm{GSSG} / 2 \mathrm{GSH}}\right)$ by approximately $47 \mathrm{mV}$ (calculated on the basis of GSH and GSSG concentration, Nernst equation) (Meyer and Hell 2005; Kranner et al. 2006).

Ascorbate and glutathione responded differently to water deficiency. A high GSH/GSSG ratio was maintained both in dehydration sensitive and tolerant seedlings because of the increased concentration of GSH and the activity of glutathione reductase. The maintenance of a high GSH/GSSG ratio and activity of glutathione reductase under drought conditions was previously observed in wheat, tomato and rice (Colville and Kranner 2010). The ratio of AsA/DHA increased in sensitive seedlings. In tolerant seedlings, after a transient increase with a mild water deficiency, the ratio dropped to the level noted for fully turgid seedlings (Fig. 1A). The differential response of ascorbate and glutathione to environmental factors illustrates the specific and distinct roles played by AsA and GSH within plants. AsA regulates primarily plant development and GSH is involved in plant development and in stress defence and signalling (Considine and Foyer 2014).

The low level of lipid peroxidation (measured as TBARS), due to a lower content of $\mathrm{H}_{2} \mathrm{O}_{2}$ in 4-day-old seedlings, confirms the involvement of the peroxidation of lipids in dehydration tolerance. This finding was previously observed in wheat seedlings, pea and tomato plants (Sánchez-Rodríguez et al. 2010). Research indicates the importance of lipid peroxidation in plant tolerance to biotic and abiotic stresses and in the selection of tolerant plants to water deficiency (Sánchez-Rodríguez et al. 2010). The stable ratio of GSH/GSSG, and a higher AsA/DHA ratio in sensitive 6-day-old seedlings compared to tolerant 4-dayold seedlings did not prevent the enhanced production of $\mathrm{H}_{2} \mathrm{O}_{2}$ and the peroxidation of lipids with dehydration. As a result, an increase in the protein carbonyl group (Fig. 2C) and a significant decrease in the thiol $(-\mathrm{SH})$ groups (Fig. 2D) were observed in dehydrated sensitive seedlings. Dehydration-induced alterations to the redox status of proteins, determined by the contents of $-\mathrm{SH}$ and carbonyl groups in proteins, are regarded as markers for oxidative stress and as signals in oxidative conditions (Suzuki et al. 2012). The observed decline in the content of protein $-\mathrm{SH}$ groups because of the formation of disulfides plays a role in metabolic regulation (Møller et al. 2011). Higher carbonylation, controlling protein quality and metabolism (Nyström 2005), results in the development of dehydration intolerance during the transition of wheat seedlings from heterotrophic to autotrophic growth (Bogdan and Zagdańska 2009; Lounifi et al. 2013).
The removal of oxidatively modified proteins in plant cells is important. If these proteins are not degraded, they tend to form high molecular weight aggregates because of covalent cross-linking and/or increased surface hydrophobicity (Karmous et al. 2014). The breakdown of oxidized proteins generated under various stress conditions is performed by ubiquitin-dependent and ubiquitin-independent proteasomal pathways. Some proteinases may be involved in the degradation of oxidized proteins (Grune et al. 2005; Karmous et al. 2014). We confirmed that water deficiency enhanced azocaseinolytic activity is increased in sensitive seedlings compared to tolerant seedlings (Fig. 3B). The higher activity of acidic proteolysis, induced by water deprivation and associated with a distinct reduction of protein content, is a common response of sensitive plants to dehydration (Cruz de Carvalho et al. 2001; Hieng et al. 2004; Simova-Stoilova et al. 2010; Hameed et al. 2011). As previously reported, (Wiśniewski and Zagdańska 2001; Grudkowska and Zagdańska 2010; Simova-Stoilova et al. 2010) cysteine proteinases were the most active proteinases during a water deficiency. Their activity increased with increased water deficit in both sensitive and tolerant seedlings. The activities of serine and metalloproteinases were fluctuating and demonstrated a tendency to increase over $15 \%$ WSD. The activity of aspartate proteinases remained at a level identical to well-watered seedlings. The involvement of serine proteinase in a plant's response to dehydration is equivocal. The activity of serine proteinase in Phaseolus vulgaris was either decreased (Cruz de Carvalho et al. 2001) or increased (Hieng et al. 2004). However, the activity increased in wheat (Wiśniewski and Zagdańska 2001; Hieng et al. 2004; Simova-Stoilova et al. 2010). The observed differences in plant proteolytic responses indicate that induction of proteolytic enzymes in response to a particular stress is species-specific.

The repression of azocaseinolytic activity at $15 \%$ WSD, fully reversible at $25 \%$ WSD, was an initial response of sensitive seedlings to water deficiency. This result was also true for frost- sensitive wheat seedlings (Grudkowska and Zagdańska 2010) and drought-sensitive wheat genotypes (Hameed et al. 2011). An increase in protein carbonyl groups and oxidized protein thiol groups, with a concomitant significant repression of proteolytic activity, is commonly associated with cellular senescence (Smakowska et al. 2014). An increased concentration of carbonylated proteins, facilitated by the decreased intensity of protein hydrolysis, indicates the ability of wheat seedlings to counteract the detrimental effects of water deficiency. Similarly, carbonylated proteins could promote the degradation of misfolded, damaged or unnecessary proteins (Grudkowska and Zagdańska 2004; Nyström 2005). Otherwise, dehydration-induced alterations in protein oxidation may result in the development of drought sensitivity. 
Open Access This article is distributed under the terms of the Creative Commons Attribution 4.0 International License (http://crea tivecommons.org/licenses/by/4.0/), which permits unrestricted use, distribution, and reproduction in any medium, provided you give appropriate credit to the original author(s) and the source, provide a link to the Creative Commons license, and indicate if changes were made.

\section{References}

Bogdan J, Zagdańska B (2009) Alterations in sugar metabolism coincide with a transition of wheat seedlings to dehydration intolerance. Environ Exp Bot 66:186-194. doi:10.1016/j.envexp bot.2009.02.013

Bradford MM (1976) A dye binding assay for protein. Anal Biochem 72:248-254. doi:10.1016/0003-2697(77)90725-4

Chen C, Letnik I, Hacham Y, Dobrev P, Ben-Daniel BH, Vanková R, Amir R, Miller G (2014) ASCORBATE PEROXIDASE6 protects Arabidopsis desiccating and germinating seeds from stress and mediates cross talk between reactive oxygen species, abscisic acid, and auxin. Plant Physiol 166:370-383. doi:10. 1104/pp.114.245324

Colville L, Kranner I (2010) Desiccation tolerant plants as model systems to study redox regulation of protein thiols. Plant Growth Regul 62:241-255. doi:10.1007/s10725-010-9482-9

Considine MJ, Foyer CH (2014) Redox regulation of plant development. Antioxid Redox Signal 21:1305-1326. doi:10.1089/ars. 2013.5665

Cruz de Carvalho MH, d'Arcy-Lameta A, Roy-Macauley H, Gareil M, El-Maarouf H, Pham-Thi AT, Zuily-Fodil Y (2001) Aspartic protease in leaves of common bean (Phaseolus vulgaris L.) and cowpea (Vigna unguiculata L. Walp): enzymatic activity, gene expression and relation to drought susceptibility. FEBS Lett 492:242-246. doi:10.1016/s0014-5793(01)02259-1

De Kok LJ, Kuiper PJC (1986) Effect of short-term dark incubation with sulfate, chloride and selenate on the glutathione content of spinach leaf discs. Physiol Plant 68:477-482. doi:10.1111/j. 1399-3054.1986.tb03385.x

Ellman GL (1959) Tissue sulfhydryl groups. Arch Biochem Biophys 82:70-77. doi:10.1016/0003-9861(59)90090-6

Frottin F, Espagne C, Traverso JA, Mauve C, Valot B, LelargeTrouverie C, Zivy M, Noctor G, Meinnel T, Giglione C (2009) Cotranslational proteolysis dominates glutathione homeostasis to support proper growth and development. Plant Cell 21: 3296-3314. doi:10.1105/tpc.109.069757

Gill SS, Tuteja N (2010) Reactive oxygen species and antioxidant machinery in abiotic stress tolerance in crop plants. Plant Physiol Biochem 48:909-930. doi:10.1016/j.plaphy.2010.08.016

Gronwald JW, Fuerst EP, Eberlein CV, Egli MA (1987) Effect of herbicide antidotes on glutathione content and glutathione S-transferase activity of sorghum shoots. Pestic Biochem Physiol 29:66-76. doi:10.1016/0048-3575(87)90085-x

Grudkowska M, Zagdańska B (2004) Multifunctional role of plant cysteine proteinases. Acta Biochim Pol 51(3):609-624

Grudkowska M, Zagdańska B (2010) Acclimation to frost alters proteolytic response of wheat seedlings to drought. J Plant Physiol 167:1321-1327. doi:10.1016/j.jplph.2010.05.019

Grune T, Merker K, Jung T, Sitte N, Davie KJ (2005) Protein oxidation and degradation during postmitotic senescence. Free Radic Biol Med 39:1208-1215. doi:10.1016/j.freeradbiomed. 2005.06.009

Hameed A, Bibi N, Akhter J, Iqbal N (2011) Differential changes in antioxidants, proteases, and lipid peroxidation in flag leaves of wheat genotypes under different levels of water deficit conditions. Plant Physiol Biochem 49:178-185. doi:10.1016/j.plaphy. 2010.11.009

Heath RL, Packer L (1968) Photoperoxidation in isolated chloroplasts. Kinetics and stoichiometry of fatty acid peroxidation. Arch Biochem Biophys 125:189-198. doi:10.1016/0003-9861(68)90 654-1

Henmi K, Demura T, Tsuboi S, Fukuda H, Iwabuchi M, Ogawa K (2005) Change in the redox state of glutathione regulates differentiation of tracheary elements in Zinnia cells and Arabidopsis roots. Plant Cell Physiol 46:1757-1765. doi:10. 1093/pcp/pci198

Hieng B, Ugrinovic K, Vozlic JS, Kidric M (2004) Different classes of protease are involved in the response to drought of Phaseolus vulgaris L. cultivars differing in sensitivity. J Plant Physiol 161:519-530. doi:10.1078/0176-1617-00956

Jana S, Choudhuri M (1981) Glycolate metabolism of three submerged aquatic angiosperms during aging. Aquat Bot 12:345-354. doi:10.1016/0304-3770(81)90047-4

Jubany-Mari T, Munne-Bosch S, Lopez-Carbonell M, Alegre L (2009) Hydrogen peroxide is involved in the acclimation of the Mediterranean shrub, Cistus albidus L., to summer drought. J Exp Bot 60:107-120. doi:10.1093/jxb/ern274

Karmous I, Chaoui A, Jaouani K, Sheehan D, Ferjani E, Scoccianti V, Crinelli R (2014) Role of the ubiquitin-proteasome pathway and some peptidases during seed germination and copper stress in bean cotyledons. Plant Physiol Biochem 76:77-85. doi:10.1016/ j.plaphy.2013.12.025

Kholová J, Hash CT, Kocŏvá M, Vadez V (2011) Does the control of reactive oxygen species matter for the terminal drought tolerance of pearl millet [Pennisetum glaucum (L.) R. Br.]? Environ Exp Bot 71:99-106. doi:10.1016/j.envexpbot.2010.11.001

Koch K (2004) Sucrose metabolism: regulatory mechanisms and pivotal roles in sugar sensing and plant development. Curr Opin Plant Biol 7:235-246. doi:10.1016/j.pbi.2004.03.014

Kranner I, Birtić S, Anderson KM, Pritchard HW (2006) Glutathione half-cell reduction potential: a universal stress marker and modulator of programmed cell death? Free Radic Biol Med 14:2155-2165. doi:10.1016/j.freeradbiomed.2006.02.013

Laemmli UK (1970) Cleavage of structural proteins during the assembly of the head of bacteriophage T4. Nature 227(5259):680-685. doi:10.1038/227680a0

Levine RL, Williams JA, Stadtman ER, Shacter E (1994) Carbonyl assays for determination of oxidatively modified proteins. Methods Enzymol 233:346-357. doi:10.1016/S0076-6879(94) 33040-9

Lounifi I, Arc E, Molasiotis A, Job D, Rajjou L, Tanou G (2013) Interplay between protein carbonylation and nitrosylation in plants. Proteomics 13:568-578. doi:10.1002/pmic.201200304

Meyer AJ, Hell R (2005) Glutathione homeostasis and redoxregulation by sulfhydryl groups. Photosynth Res 86:435-457. doi:10.1007/s11120-005-8425-1

Miazek A, Bogdan J, Zagdańska B (2001) Effects of water deficit during germination of wheat seeds. Biol Plant 44:397-403. doi:10.1023/A:1012455112853

Mittler R, Zilinskas BA (1993) Detection of peroxidase activity in native gels by inhibition of ascorbate-dependent reduction of nitroblue tetrazolium. Anal Biochem 212:540-546. doi:10.1016/ j.tplants.2004.08.009

Møller IM, Rogowska-Wrzesinska A, Rao RS (2011) Protein carbonylation and metal-catalyzed protein oxidation in a cellular perspective. J Proteom 74:2228-2242. doi:10.1016/j.jprot.2011. 05.004

Nakano Y, Asada K (1981) Hydrogen peroxide is scavenged by ascorbate-specific peroxidase in spinach chloroplasts. Plant Cell Physiol 22:867-880 
Noctor G, Foyer CH (1998) Ascorbate and glutathione: keeping active oxygen under control. Annu Rev Plant Physiol Plant Mol Biol 49:249-279. doi:10.1146/annurev.arplant.49.1.249

Noctor G, Mhamdi A, Foyer CH (2014) The roles of reactive oxygen metabolism in drought: not so cut and dried. Plant Physiol 164:1636-1648. doi:10.1104/pp.113.233478

Nyström T (2005) Role of oxidative carbonylation in protein quality control and senescence. EMBO J 24:1311-1317. doi:10.1038/sj. emboj. 7600599

Omaye ST, Turbull TP, Sauberchich HC (1979) Selected methods for determination of ascorbic acid in cells, tissues and fluids. Methods Enzymol 6:3-11. doi:10.1016/0076-6879(79)62181-X

Pyngrope S, Bhoomika K, Dubey RS (2013) Oxidative stress, protein carbonylation, proteolysis and antioxidative defense system as a model for depicting water deficit tolerance in Indica rice seedlings. Plant Growth Regul 69:149-165. doi:10.1007/ s10725-012-9758-3

Rao MV, Paliyath G, Ormrod DP (1996) Ultraviolet-B and ozoneinduced biochemical changes in antioxidant enzymes of Arabidopsis thaliana. Plant Physiol 110:125-136. doi:10.1104/pp. 110.1.125

Rinalducci S, Murgiano L, Zolla L (2008) Redox proteomics: basic principles and future perspectives for the detection of protein oxidation in plants. J Exp Bot 59:3781-3801. doi:10.1093/jxb/ ern252

Sánchez-Rodríguez E, Rubio-Wilhelmi M, Cervilla LM, Blasco B, Rios JJ, Rosales MA, Romero L, Ruiz JM (2010) Genotypic differences in some physiological parameters symptomatic for oxidative stress under moderate drought in tomato plants. Plant Sci 178:30-40. doi:10.1016/j.plantsci.2009.10.001

Simova-Stoilova L, Vaseva I, Grigorova B, Demirevska K, Feller U (2010) Proteolytic activity and cysteine protease expression in wheat leaves under severe soil drought and recovery. Plant Physiol Biochem 48:200-206. doi:10.1016/j.plaphy.2009.11.003 Smakowska E, Czarna M, Janska H (2014) Mitochondrial ATPdependent proteases in protection against accumulation of carbonylated proteins. Mitochondrion 19:241-251. doi:10. 1016/j.mito.2014.03.005

Sperdouli I, Moustakas M (2014) Leaf developmental stage modulates metabolite accumulation and photosynthesis contributing to acclimation of Arabidopsis thaliana to water deficit. J Plant Res 127:481-489. doi:10.1007/s10265-014-0635-1

Suzuki N, Koussevitzky S, Mittler R, Miller G (2012) ROS and redox signalling in the response of plants to abiotic stress. Plant Cell Environ 35:259-270. doi:10.1111/j.1365-3040.2011.02336.x

Tommasi F, Paciolla C, de Pinto MC, De Gara L (2001) A comparative study of glutathione and ascorbate metabolism during germination of Pinus pinea L. seeds. J Exp Bot 362:1647-1654. doi:10.1093/jexbot/52.361.1647

Turner NC (1981) Techniques and experimental approaches for the measurement of plant water status. Plant Soil 58:339-366. doi:10.1007/BF02180062

Voos W (2013) Chaperone-protease networks in mitochondrial protein homeostasis. Biochim Biophys Acta 1833:388-399. doi:10.1016/j.bbamcr.2012.06.005

Wiśniewski K, Zagdańska B (2001) Genotype-dependent proteolytic response of spring wheat to water deficiency. J Exp Bot 52:1455-1463. doi:10.1093/jexbot/52.360.1455

Xiong Y, Contento AL, Nguyen PQ, Bassham DC (2007) Degradation of oxidized proteins by autophagy during oxidative stress in Arabidopsis. Plant Physiol 143:291-299. doi:10.1104/pp.106.092106

Yoshimura K, Yabuta Y, Ishikawa T, Shigeoka S (2000) Expression of ascorbate peroxidase isoenzymes in response to oxidative stresses. Plant Physiol 123:223-233. doi:10.1104/pp.123.1.223 